\title{
PERENCANAAN DISAIN PENGELOLAAN SUMBERDAYA PERIKANAN BERBASIS SISTEM INFROMASI MANAJEMEN
}

\author{
Umar Tangke \\ Staf Pengajar FAPERTA UMMU-Ternate,e-mail: khakafart@yahoo.com
}

\begin{abstract}
ABSTRAK
Pengelolaan sumberdaya Perikanan harus dilakukan secara bertanggung jawab dan tepat, dengan memanfaatkan data yang kontinyu dan teknologi yang mampu menggambarkan wilayah, potensi sumberdaya perikanan dengan baik. Integrasi penginderaan jauh dan Sistem Informasi Geografi (SIG) merupakan salah satu cara untuk mengelola sumberdaya perikanan dengan data yang kontinyu dan sebaran spasial yang bisa menampilkan secara sederhana bentuk dan potensi sumberdaya perikanan. Tantangan dalam pengembangan usaha perikanan di Indonesia adalah lemahnya sistem data base dan sistem informasi perikanan yang berpengaruh terhadap akurasi dan ketepatan waktunya, kelemahan ini dapat mengakibatkan salah perencanaan akan berakibat pada kegagalan usaha, sehingga dalam merencanakan disain pengelolaan sumberdaya perikanan berbasis sistem informasi manajemen, perlu beberapa kegiatan yang dilaksanakan diantaranya (1) penyempurnaan metode dan kerangka survei statistik perikanan, (2) penyempurnaan buku pedoman survei statistik perikanan, (3) pengembangan sistem data statistik, (4) pelatihan enumerator dan supervisor pengumpulan data serta pengolah data, (5) uji coba pedoman survei statistik perikanan dan (6) sosialisasi sistem data statistik.
\end{abstract}

Kata Kunci: SIM, sistem informasi, sumberdaya perikanan

\section{Pendahuluan}

\subsection{Latar Belakang}

Potensi sumberdaya kelautan dan perikanan, merupakan salah satu komoditas unggulan yang harus dikelola secara baik dan arif. Untuk itu diperlukan kapabilitas sumberdaya manusia yang dapat diandalkan untuk mengelola potensi tersebut secara profesional dan berkelanjutan. Keberlanjutan merupakan kata kunci dalam pembangunan perikanan yang diharapkan dapat memperbaiki kondisi sumberdaya dan kesejahteraan masyarakat perikanan itu sendiri (Fauzi dan Anna, 2002).

Sumberdaya kelautan dan perikanan dapat dibagi atas empat kelompok, (1) sumberdaya dapat pulih (renewable resources), (2) sumberdaya tidak dapat pulih (non-renewable resources), (3) energi kelautan, dan (4) jasa-jasa lingkungan kelautan (environmental services). Sumberdaya dapat pulih terdiri dari sumberdaya perikanan tangkap dan sumberdaya perikanan budidaya (pantai/tambak dan laut) sedangkan sumberdaya tak dapat pulih meliputi mineral, bahan tambang/galian, minyak bumi dan gas.
Potensi sumberdaya kelautan dan perikanan ini masih belum banyak yang digarap secara optimal karena informasinya belum ditempatkan dalam suatu sistem basis data yang terpadu sehingga menyulitkan dalam pencahariannya.

Salah satu sifat sumberdaya ikan adalah sangat dinamis yang dapat berubah dengan cepat sesuai dengan ruang dan waktu dan dengan kondisi lautan yang sangat luas, maka untuk pengelolaan sumberdaya ikan diperlukan informasi yang lebih spesifik baik secara temporal maupun secara spasial. Masih banyak informasi mengenai sumberdaya perikanan yang belum tersedia misalnya dimana ikan berada, kapan, jenis apa saja, berapa banyak, daerah mana yang belum dimanfaatkan, bagaimana pengaruh kondisi oseanografi terhadap sumberdaya dan sebagainya.

Melihat potensi perikanan yang begitu besar maka diperlukan adanya upaya pengelolaan, dimana upaya tersebut diharapkan dapat membantu nelayan dan pengguna lain (stakeholder) untuk meningkatkan produksi hasil tangkapan dan produksi budidaya dengan tidak 
mengganggu potensi dan kelestarian sumberdaya di perairan serta menghindari terjadinya kerusakan pada stok sumberdaya perikanan seperti lebih tangkap (overfishing) dan mencegah penangkapan ikan dengan menggunakan alat dan bahan yang bersifat merusak, seperti penangkapan ikan karang dengan alat muroami dan penggunaan potasium.

Pengelolaan sumberdaya Perikanan harus dilakukan secara bertanggung jawab dan tepat, dengan memanfaatkan data yang kontinyu dan teknologi yang mampu menggambarkan wilayah, potensi sumberdaya perikanan dengan baik. Integrasi penginderaan jauh dan Sistem Informasi Geografi (SIG) merupakan salah satu cara untuk mengelola sumberdaya perikanan dengan data yang kontinyu dan sebaran spasial yang bisa menampilkan secara sederhana bentuk dan potensi sumberdaya perikanan. Secara sederhana intergrasi antara penginderaan jauh dan SIG dapat memetakan kondisi sumberdaya perikanan sehingga dapat dipantau kondisinya.

\subsection{Tujuan Penulisan}

Tujuan Penulisan artikel ini adalah untuk membahas perencanaan disain pengelolaan sumberdaya perikanan berbasis sistem informasi manajemen (SIM).

\section{SUMBERDAYA PERIKANAN}

Potensi sumberdaya perikanan terdiri dari sumberdaya perikanan tangkap, budidaya pantai (tambak), budidaya laut, dan bioteknologi kelautan. Potensi perikanan laut sesungguhnya merupakan asset yang sangat besar bagi pertumbuhan ekonomi Indonesia. Namun asset ini belum dimanfaatkan secara maksimal. Potensi perikanan laut meliputi perikanan tangkap, budidaya laut, dan industri bioteknologi kelautan. Potensi perikanan laut menurut Dahuri, (2001) sebagai berikut :

\subsection{Potensi Perikanan Tangkap}

Potensi perikanan tangkap diperkirakan mencapai 6,26 juta ton per tahun dengan jumlah tangkapan yang diperbolehkan sebesar 5.007 juta ton atau $80 \%$ dari MSY (Maximum Sustainable Yield). Hingga saat ini jumlah tangkapan mencapai 3,5 juta ton sehingga tersisa peluang sebesar 1,5 ton/tahun. Seluruh potensi perikanan tangkap tersebut diperkirakan memiliki nilai ekonomi sebesar US\$15.1 milyar.

\subsection{Potensi Budidaya Laut}

Potensi budidaya laut terdiri dari total potensi budidaya ikan, udang, moluska dan budidaya rumput laut. Potensi budidaya laut diperkirakan sebesar 46,73 juta ton per tahun.

\subsection{Potensi Bioteknologi}

Potensi bioteknologi kelautan juga masih besar untuk mengembangkan industri bioteknologi kelautan seperti industri bahan baku untuk makanan, industri bahan pakan alami, benih ikan dan udang, industri bahan pangan. Nilai ekonomi dari potensi bioteknologi kelautan tersebut diperkirakan mencapai US\$ 40 milyar.

\section{SISTEM INFORMASI MANAJEMEN PERIKANAN}

Sistem adalah kumpulan elemen yang berintegrasi untuk mencapai tujuan tertentu, sedangkan informasi adalah data yang telah diolah menjadi bentuk yang lebih berarti bagi penerimanya dan bermanfaat dalam mengambil keputusan saat ini atau mendatang (Davis, 1999). Informasi dapat menggambarkan kejadian nyata yang digunakan untuk pengambilan keputusan. Sumber dari informasi adalah data yang dapat berbentuk huruf, simbol, alfabet dan lain sebagainya. Sistem informasi memiliki tiga elemen utama, yaitu data yang menyediakan informasi, prosedur yang memberitahu pengguna bagaimana mengoperasikan sistem informasi, dan orang-orang yang membuat produk, menyelesaikan masalah, membuat keputusan, dan menggunakan sistem informasi tersebut. Orangorang dalam sistem informasi membuat prosedur untuk mengolah dan memanipulasi data sehingga menghasilkan informasi dan menyebarkan informasi tersebut ke lingkungan (Soselisa, 2001).

Model dasar sistem adalah masukan, pengolahan, dan pengeluaran. Fungsi pengolahan informasi sering membutuhkan data yang telah dikumpulkan dan diolah dalam waktu periode sebelumnya. Oleh karena itu pada model sistem informasi ditambahkan pula media penyimpan data (data base) maka fungsi pengolahan informasi bukan lagi mengubah data menjadi informasi tetapi juga menyimpan data untuk penggunaan lanjutan. Model dasar ini berguna dalam memahami bukan saja keseluruhan sistem pengolahan informasi, tetapi juga untuk penerapan pengolahan informasi secara tersendiri. Setiap penerapan dapat dianalisis menjadi masukan, penyimpanan, pengolahan dan keluaran. Keberhasilan suatu sistem informasi 
sangat bergantung pada sistem basis data. Semakin lengkap, akurat dan mudah dalam menampilkan kembali data yang ada dalam sistem basis data maka akan semakin tinggi kualitas sistem informasi tersebut (Soselisa, 2001).

Basis data (database) merupakan kumpulan dari data yang saling berhubungan satu dengan lainnya, tersimpan di perangkat keras komputer dan digunakan perangkat lunak untuk memanipulasinya. Data perlu disimpan di dalam basis data untuk keperluan penyediaan informasi lebih lanjut. Dengan ditambahkannya penyimpanan data, fungsi pengolahan infomasi bukan lagi mengubah data menjadi informasi tetapi juga menyimpan data untuk penggunaan lanjutan (Jogiyanto, 1999).

Menurut Murdick, R.G \& J.E. Ross dalam (Susana, T. et al, 2004) , Sistem Informasi
Manajemen adalah proses komunikasi di mana informasi masukan (input) direkam, disimpan, dan diproses untuk menghasilkan output yang berupa keputusan tentang perencanaan, pengoperasian dan pengawasan, selanjutnya dikatakan oleh Kelly, J. F, Sistem Informasi Manajemen adalah perpaduan sumberdaya manusia dan sumberdaya yang berbasis komputer yang menghasilkan kumpulan penyimpanan, komunikasi, dan penggunaan data untuk tujuan operasi managemen yang efisien serta perencanaan bisnis.

Sistim ini menggunakan perangkat keras dan perangkat lunak komputer, prosedur pedoman, model manajemen, dan keputusan serta sebuah basis data (database). Komponen sistem informasi manajemen dapat dilihat pada tabel 1.

Tabel 1. Komponen Sistem Informasi Manajemen

\begin{tabular}{|c|c|}
\hline Komponen Sistim & Keterangan \\
\hline Perangkat Keras & $\begin{array}{l}\text { Terdiri atas : Komputer (pusat pengolah, unit masukan/keluaran, unit penyimpanan file, dsb), } \\
\text { penyiapan data, dan terminal masukan/ keluaran }\end{array}$ \\
\hline Perangkat Lunak & $\begin{array}{l}\text { Terbagi dalam } 3 \text { jenis : } \\
\text { - } \quad \text { sistim perangkat lunak umum (pengoperasian komputer), } \\
\text { - } \quad \text { aplikasi perangkat lunak umum (model analisis dan keputusan) } \\
\text { - } \quad \text { aplikasi perangkat lunak yang terdiri atas program spesifik yang dibuat untuk setiap aplikasi }\end{array}$ \\
\hline Database & $\begin{array}{l}\text { - } \quad \text { File yang berisi program dan data dibuktikan dgn adanya media penyimpanan secara fisik } \\
\text { seperti disket, hard disk, magnetik tape dsb. } \\
\text { - } \quad \text { File juga berisi keluaran tercetak dan cacatan lain di atas kertas, mikro film dsb }\end{array}$ \\
\hline Prosedur & $\begin{array}{l}\text { Merupakan komponen fisik karena disediakan dalam bentuk fisik seperti buku panduan dan } \\
\text { instruksi, Ada tiga prosedur yang dibutuhkan yaitu : } \\
\text { - instruksi untuk pemakai, } \\
\text { - intruksi untuk penyiapan masukan, } \\
\text { - instruksi pengoperasian untuk karyawan pusat komputer }\end{array}$ \\
\hline Personil & Operator komputer, analisis sistim, programmer, personil data entri dan manager Sistim Informasi \\
\hline
\end{tabular}

Salah satu contoh penggunaan perangkat lunak dalam sistem informasi manajemen yaitu Sistem Informasi Geografi (SIG), dimana sistem informasi ini dirancang untuk bekerja dengan data yang bereferensi spasial atau berkoordinat geografi atau dengan kata lain suatu SIG adalah suatu sistem basis data dengan kemampuan khusus untuk menangani data yang bereferensi keruangan (spasial) bersamaan dengan seperangkat operasi kerja (Barus dan Wiradisastra, 2000). Aplikasi SIG dapat digunakan untuk berbagai kepentingan selama data yang diolah memiliki referensi geografi, maksudnya data tersebut terdiri dari fenomena atau objek yang dapat disajikan dalam bentuk fisik serta memiliki lokasi keruangan. Selain itu kita dapat menggunakan penginderaan jauh yang merupakan suatu metode untuk pengenalan dan penentuan objek dipermukaan bumi tanpa harus melakukan kontak langsung dengan objek tersebut. Data penginderaan jauh dapat bersifat kontinyu karena mempunyai resolusi temporal, dapat digunakan untuk berbagai aplikasi karena resolusi spektralnya dan ditampilkan dalam berbagai bentuk skala karena resolusi spasilanya.

\section{PEMANFAATAN SISTEM INFORMASI MANAJEMEN PADA PENGELOLAAN SUMBERDAYA PERIKANAN}

\section{1 . Tantangan dan Permasalahan}

Permintaan terhadap produksi perikanan Indonesia semakin meningkat, hal menyebabkan tuntutan untuk peningkatan produksi perikanan, tetapi dalam berbagai hal, terdapat permasalahan 
yang dihadapi khususnya dalam menerapkan pemanfaatan sumberdaya perikanan secara berkelanjutan. Oleh karena itu untuk memenuhi permintaan tersebut maka tantangan utama yang dihadapi oleh bangsa Indonesia dalam pembangunan perikanan adalah: (1) Peningkatan kualitas SDM perikanan dan penguasaan IPTEK untuk mendukung peningkatan produksi; (2) Pengembangan teknologi perikanan yang berwawasan lingkungan sebagai upaya untuk menjaga kualitas produksi dan kualitas lingkungan; dan (3) Menjaga dan mengamankan keberlanjutan sumberdaya perikanan baik dari ancaman pencurian maupun over-eksploitasi sumberdaya yang berlebihan.

Tantangan dalam pengembangan usaha perikanan di Indonesia adalah lemahnya sistem data base dan sistem informasi perikanan yang berpengaruh terhadap akurasi dan ketepatan waktunya, kelemahan ini dapat mengakibatkan salah perencanaan akan berakibat pada kegagalan usaha. Namun pada masa sekarang dimana sumberdaya tersebut telah dimanfaatkan dan keadaan lingkungan yang semakin memburuk ketepatan data dan timingnya menjadi sangat menentukan. Tantangan lain adalah kualitas sumberdaya manusia, karena untuk membangun suatu sistem informasi dibutuhkan sumberdaya manusia yang berkualitas dan mampu menguasai teknologi sistem informasi serta mengoperasikannya.

Salah satu permasalahan pembangunan perikanan Indonesia adalah keterbatasan data dan informasi yang dapat dijadikan rujukan perencanaan dan pengelolaan sumberdaya perikanan. Ketersediaan data dan informasi perikanan yang akurat hingga saat ini masih dipandang sebagai hal yang tidak begitu penting dan mendesak dalam pembangunan perikanan nasional. Hingga saat ini, belum ada lembaga yang menangani penyediaan data dan informasi secara menyeluruh, melainkan masih dilakukan oleh masing-masing instansi sesuai dengan kebutuhan. Akibatnya sering terjadi perbedaan data dan informasi perikanan.

Suatu sistem informasi yang bersifat lintas sektor mempunyai suatu beban yang berat yaitu bagaimana menyelaraskan seluruh instansi agar tidak ada yang merasa dirugikan, bahkan seluruhnya diharapkan mempunyai inisiatif untuk bergabung demi tercapainya sistem informasi menyeluruh yang handal. Kendala dalam pengimplementasian sistem informasi yang terintegrasi adalah keberagamannya macam sistem yang telah ada sejak lama yang tersebar di berbagai instansi baik pemerintah maupun swasta, baik sipil maupun militer, baik di daerah maupun di pusat. Keberagaman ini semakin bertambah parah dikarenakan pada kenyataannya tidak seluruh peralatan penunjang pengumpul data bekerja penuh secara elektronik, akan tetapi masih banyak pula yang semi-elektronik dan bahkan non-elektronik, sehingga hal ini benarbenar akan menimbulkan kesulitan di dalam pengintegrasiannya nanti. Jika semua peralatan harus diubah menjadi elektronik secara keseluruhan sesuai dengan tuntutan jaman informasi, maka salah satu kendala yang utama adalah mahalnya harga peralatan elektronik tersebut yang rata-rata memang masih merupakan barang impor. Hal ini mendorong kemadirian didalam peralatan-peralatan ini sudah mutlak diperlukan (Soselisa, 2001).

\subsection{Data dan Informasi Yang Diperlukan}

Informasi tentang perikanan Indonesia saat ini diperoleh dari berbagai sumber informasi baik dari instansi pemerintah, swasta ataupun masyarakat. 1) Instansi pemerintah yang dapat memberikan informasi tentang perikanan adalah departemen dan non-departemen. Departemen yang langsung berhubungan dengan perikanan adalah Departemen Kelautan dan Perikanan dan Dinas-dinas Perikanan di daerah, sementara departemen lain yang secara tidak langsung berhubungan dengan informasi perikanan adalah Departemen Perindustrian dan Perdagangan, Departemen Perhubungan, Departemen Tenaga Kerja, Departemen Keuangan, Departemen Luar Negeri, Departemen Pertahanan dan Keamanan/Polri dan Departemen Hukum dan Perundang-Undangan. Sedangkan instansi nondepartemen yang secara tidak langsung juga berhubungan dengan perikanan adalah lembagalembaga penelitian dan pengkajian seperti BPPT, LIPI, BAKOSURTANAL, dan LAPAN, serta Universitas-Universitas ; 2) Untuk pihak swasta, informasi perikanan dapat diperoleh dari perusahaan-perusahaan atau industri-industri yang bergerak dalam bidang perikanan; 3) untuk pihak masyarakat, informasi perikanan dapat diperoleh dari koperasi-koperasi unit desa (KUD) yang berusaha dalam bidang perikanan. Mereka ini berada dalam jumlah yang banyak dan tersebar di daerah-daerah yang mempunyai potensi perikanan. Disamping itu terdapat juga lembaga-lembaga sosial masyarakat (LSM) yang berusaha di bidang Perikanan.

Pembentukan sistem informsi perikanan memerlukan informasi perikanan. Informasi 
perikanan yang diperlukan dikelompokkan dalam informasi perikanan tangkap dan informasi perikanan budidaya. Informasi perikanan tangkap yang diperlukan meliputi: (1) distribusi spasial dan temporal jenis-jenis sumberdaya perikanan, (2) potensi lestari setiap jenis sumberdaya perikanan, (3) persyaratan ekologis bagi kehidupan dan pertumbuhan setiap jenis sumberdaya perikanan, (4) trophodynamics (transfer energi dan materi antar trophic level) dalam suatu ekosistem perairan dimana sumberdaya perikanan yang dikelola hidup, (5) dinamika populasi sumberdaya perikanan, (6) sejarah hidup dari sumberdaya perikanan, (7) kualitas perairan dimana sumberdaya hidup, dan (8) tingkat penangkapan/pemanfaatan terhadap sumberdaya perikanan, dalam bentuk upaya tangkap secara berkala, (9) Jumlah armada penangkapan ikan dari berbagai ukuran baik yang artisanal maupun modern secara spasial dan temporal serta jumlah nelayan yang memang benar-benar melakukan kegiatan sebagai nelayan (Soselisa, 2001).

Dalam upaya mendapat sistem informasi perikanan yang terpadu, sistem informasi perikanan Indonesia dikembangkan dengan konsep sebagai berikut:

1) Sistem informasi perikanan Indonesia dikembangkan secara bertahap dan berkelanjutan.

2) Mendayagunakan sistem-sistem yang sudah ada - baik sistem informasi maupun sistem komunikasi secara maksimal.

3) Dalam langkah pendayagunaan tersebut, maka usaha intervensi dan atau modifikasi sistem informasi yang telah ada ditekan seminimal mungkin.

4) Pemanfaatan teknologi-teknologi mutakhir, yang cocok dengan spesifikasi di atas.

Sistem informasi perikanan Indonesia pada dasarnya berfungsi sebagai infrastruktur informasi yang dapat digunakan untuk memecahkan berbagai permasalahan dan juga mengakomodir semua tujuan yang diharapkan. Sistem ini diharapkan dapat memberikan informasi yang berbasis multimedia kepada penggunanya.

Sesuai dengan tujuannya, prinsip pengembangan sistem informasi perikanan Indonesia adalah (1) mengembangkan dan menyatukan sistem informasi tentang perikanan Indonesia yang sudah ada menjadi sebuah sistem "network" perikanan, (2) mendisain dan membangun sistem informasi yang belum tersedia kemudian menyambungkannya dalam sistem network perikanan, (3) mendisain dan membangun pusat-pusat pelayanan data informasi, dan (4) merekayasa sebuah "protokol" bagi sistem "network" perikanan Indonesia (Soselisa, 2001).

\section{PERENCANAAN PENGELOLAAN SUMBERDAYA BERBASIS SIM}

Pengelolaan Sumberdaya Perikanan adalah suatu konsep yang diterapkan dibidang perikanan dengan tujuan agar pemanfaatan sumberdaya perikanan dapat dioptimalkan serta kelestarian dari potensi perikanan tetap terjaga, oleh karena itu dalam pemanfaatan dan pengelolaan suatu sumberdaya perikanan diperlukan suatu model yang dapat dipakai untuk mengoptimalkan pemanfaatan serta tetap menjaga kelestarian sumberdaya perikanan sehingga pengelolaan dapat berkelanjutan. SIM adalah suatu solusi yang tepat untuk pemanfaatan sumberdaya secara optimal serta dapat melestarikan sumberdaya. Perencanaan pengelolaan berbasis sistem informasi manajemen perikanan dapat dilakukan dengan 2 tahap yaitu :

\subsection{Ide Perencanaan SIM}

Sistem Informasi Manajemen adalah sebuah sistim manusia/mesin yang terpadu untuk menyajikan informasi guna mendukung fungsi operasi organisasi, managemen, dan proses pengambilan keputusan di dalam suatu organisasi.

Dalam kegiatan perikanan, pertanyaan klasik yang sering terdengar adalah dimana wilayah yang sesuai untuk melakukan suatu aktifitas perikanan. Meskipun sulit mencari jawabannya, perntanyaan penting ini perlu dicari solusinya. Hal ini antara lain karena usaha perikanan dengan mencari habitat yang sesuai untuk ikan yang tidak menentu akan mempunyai konsekuensi yang besar yaitu memerlukan biaya yang besar, waktu dan tenaga. Alternatif yang menawarkan solusi terbaik adalah mengkombinasikan kemampuan SIG dan penginderaan jauh (inderaja) kelautan. Dengan teknologi inderaja faktor-faktor lingkungan laut yang mempengaruhi distribusi, migrasi dan kelimpanan ikan dapat diperoleh secara berkala, cepat dan dengan cakupan area yang luas. Oleh sebab itu perlu ada ide dasar untuk membentuk suatu Sistem informasi manajemen yang menggunakan tools SIG dan Penginderaan jauh untuk dapat melakukan suatu sistem pengelolaan sumberdaya perikanan yang terpadu. 


\subsection{Disain SIM Sumberdaya Perikanan}

Sistem informasi Geografis adalah alat dengan sistem komputer yang digunakan untuk memetakan kondisi dan peristiwa yang terjadi dimuka bumi. Teknologi SIG ini dapat mengintegrasikan sistem operasi database seperti query dan analisis statik dengan berbagai keuntungan analysis geografis yang ditawarkan dalam bentuk peta. SIG memiliki kapabilitas menghubungkan berbagai lapisan data di suatu titik yang sama pada waktu tertentu, mengkombinasikan, menganalisis data tersebut dan memetakan hasilnya. Teknologi ini juga dapat mendeskripsikan karakteristik objek pada peta dan menentukan posisi koordinatnya, melakukan query dan analisis spasial serta mampu menyimpan, mengelola, mengupdate data secara terorganisir dan efisien (Zainuddin, 2006).

Bertolak dari pengertian SIG diatas maka, disain perencanaan pengelolaan sumberdaya perikanan dapat dilakukan dengan 6 tahap yaitu :

\subsubsection{Sumberdaya perikanan}

Pada tahap ini perlu adanya suatu komitmen untuk penentuan jenis sumberdaya perikanan yang akan di manfaatkan

\subsubsection{Data base}

Data base sangat berperan penting untuk tujuan pengelolaan sumberdaya kelautan dan perikanan. Data base dapat berupa data pengukuran lapangan, data digital, peta, laporan maupun data lainnya dan data base bias didapat dari berbagai sumber diantaranya instansi pemerintah maupun non-pemerintah, swasta dan masyarakat.

\subsubsection{Manajemen dan manipulasi data}

Pada tahap ini semua data di analisis dengan menggunakan sistem analisis dengan barbagai program yang kemudian ditranfers ke program SIG untuk melakukan proses untuk menghasilkan bahan informasi yang dapat berupa peta tematik dan laporan akhir. Pada tahap ini proses dimulai dari proses pemasukan data base kemudian selanjutnya di lakukan proses manajemen dan manipulasi, pada proses manajemen dan manipulasi proses yang dilakukan melalui sub-sub sistem sebagai berikut :

a. Data Input : sub sistem ini berfungsi mengumpulkan dan mempersiapkan data spasial dan atribut dari berbagai sumber sekaligus bertanggung jawab dalam mengkonversi atau mentransformasikan format-format data aslinya kedalam format yang dapat digunakan oleh SIG. b. Data Storage and Retrieval: sub sistem ini mengorganisasikan baik data spasial maupun atribut kedalam sebuah basis data sehingga mudah dipanggil, diperbaharui dan diedit.

c. Data manipulation \& analysis : sub sistem ini menentukan informasi-informasi yang dapat dihasilkan oleh SIG. selain itu, juga melakukan manipulasi dan pemodelan data untuk menghasilkan informasi yang diharapkan.

d. Data output/reporting : sub sistem ini menampilkan keluaran seluruh atau sebagian basis data baik dalam bentuk soft copy maupun hard copy seperti tabel, grafik dan lain-lain.

Selanjutnya hasil proses (out put) yang berupa peta, citra satelit dan laporan yang kemudian dilakukan pengawasan. Setelah pengawasan dilakukan model pengelolaan ini masuk ketahap selanjutnya yaitu tahap evaluasi jika model sudah sesaui maka dilanjutkan dengan proses pelaksanaan pembangunan pengelolaan tersebut, tetapi jika belum sesuai maka, dilakukan evaluasi terhadap data base serta manajemen dan manipulasi data.

\subsubsection{Pengawasan Sistem Informasi Manajemen Sumberdaya Perikanan}

Pada tahap ini pengawasan hanya dilakukan untuk melihat apakah model tersebut sudah sesuai dengan tujuan pengelolaan sumberdaya perikanan atau kah tidak.

\subsubsection{Evaluasi Sistem Informasi Manajemen Sumberdaya Perikanan}

Evaluasi bersama secara terpadu dengan melibatkan seluruh pihak yang berkepentingan. Melalui evaluasi ini akan diketahui kelemahan dan kelebihan dari perencanaan yang ada guna perbaikan untuk pelaksanaan tahap berikutnya.

\subsubsection{Pelaksanaan Sistem Informasi} Manajemen Sumberdaya Perikanan

Pada tahap implementasi ini juga diperlukan kesamaan persepsi antara masyarakat lokal dengan lembaga atau orang-orang yang terlibat dalam pelaksanaan kegiatan ini sehingga masyarakat benar-benar memahami rencana yang akan dilaksanakan. Menurut Zamani dan Darmawan (2000) kegiatan-kegiatan yang perlu dilakukan pada tahap implementasi ini adalah: (1) integrasi ke dalam masyarakat, dengan melakukan pertemuan dengan masyarakat untuk menjawab seluruh pertanyaan yang berhubungan dengan penerapan konsep dan mengidentifikasi pemimpin potensial yang terdapat di lembaga masyarakat lokal. (2) pendidikan dan pelatihan masyarakat, metoda pendidikan dapat dilakukan 
secara non formal menggunakan kelompokkelompok kecil dengan cara tatap muka sehingga dapat diperoleh informasi dua arah dan pengetahuan masyarakat lokal (indigenous knowledge) dapat dikumpulkan untuk dimasukkan dalam konsep penerapan (3) memfasilitasi arah kebijakan, dalam hal ini segenap kebijakan yang berasal dari masyarakat dan telah disetujui oleh koordinator pelaksana hendaknya dapat didukung oleh pemerintah daerah, sehingga kebijakan bersama tersebut mempunyai kekuatan hukum yang jelas, dan (4) penegakan hukum dan peraturan, yang dimaksudkan agar seluruh pihak yang terlibat akan dapat menyesuaikan tindakannya dengan hukum dan peraturan yang berlaku.

Secara umum tahap-tahap dalam perencanaan disain pengelolaan sumberdaya perikanan dapat lihat pada gambar 1 .

\section{PENUTUP}

Sumberdaya perikanan, merupakan salah satu komoditas unggulan yang harus dikelola secara baik dan arif. Oleh karena diperlukan perencanaan Sistim Informasi manajemen pengelolaan dan pembangunan Sistim informasi manajemen pengelolaan untuk pemanfaatan berkelanjutan sehingga sumberdaya perikanan dapat terjaga kelestariannya. Salah satu contoh penggunaan perangkat lunak dalam sistem informasi manajemen yaitu Sistem Informasi Geografi (SIG) dimana sistem informasi ini dirancang untuk bekerja dengan data yang bereferensi spasial atau berkoordinat geografi atau dengan kata lain suatu SIG adalah suatu sistem basis data dengan kemampuan khusus untuk menangani data yang bereferensi keruangan (spasial) bersamaan dengan seperangkat operasi kerja (Barus dan Wiradisastra, 2000). Aplikasi SIG dapat digunakan untuk berbagai kepentingan selama data yang diolah memiliki referensi geografi, maksudnya data tersebut terdiri dari fenomena atau objek yang dapat disajikan dalam bentuk fisik serta memiliki lokasi keruangan.

Pengembangan data dan informasi sebagai bahan perencanaan pembangunan perikanan haruslah mengintegrasikan data-data lainnya seperti aspek lingkungan, sosial dan ekonomi. Sehubungan dengan sifat yang dinamis dan kompleksitas dari sumberdaya perikanan, maka ketersediaan data yang akurat dan terpecaya menjadi penting. Dalam merencanakan disain pengelolaan sumberdaya perikanan berbasis sistem informasi manajemen, perlu beberapa kegiatan yang dapat dilaksanakan adalah (1) penyempurnaan metode dan kerangka survei statistik perikanan, (2) penyempurnaan buku pedoman survei statistik perikanan, (3) pengembangan sistem data statistik, (4) pelatihan enumerator dan supervisor pengumpulan data serta pengolah data, (5) uji coba pedoman survei statistik perikanan dan (6) sosialisasi sistem data statistik.

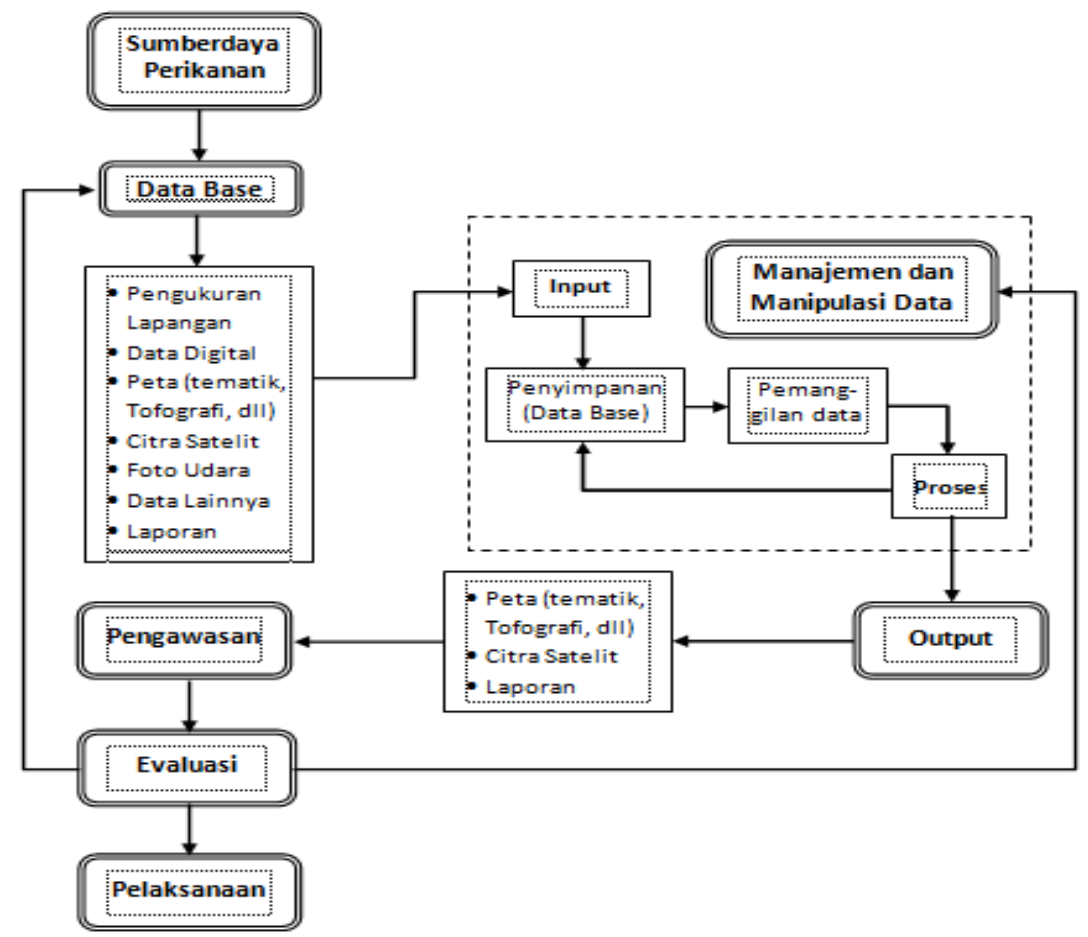

Gambar 1. Model Perencanaan Disain Pengelolaan Sumberdaya Perikanan 


\section{DAFTAR PUSTAKA}

Barus, Baba., dan U.S. Wiradisastra., 2000. Sistem Informasi Geografi; Sarana Manajemen Sumberdaya. Laboraturium Pengindraan Jauh dan Kartografi Jurusan Tanah Fakultas Pertanian IPB. Bogor.

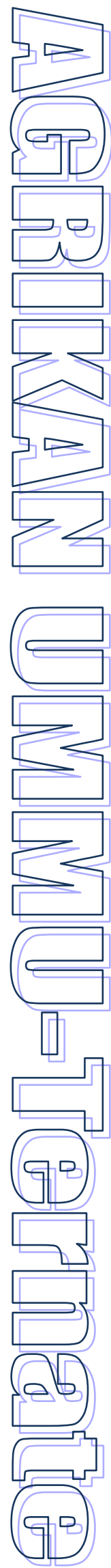

Cholik, F. 2000. Kondisi Perikanan Peluang dan Tantangan. Makalah disajikan pada Seminar Nasional dan Talk Show Marine Techno and Fisheries 2000, Jakarta. 8 - 9 Agustus.

Dahuri, R., J.Rais, S.P. Ginting, dan M.J. Sitepu. 2001. Pengelolaan Sumberdaya Pesisir dan Lautan Secara Terpadu. Pradnya Paramita. Jakarta.

Damardjati, D.S., I.G. Ismail dan T. Alihamsyah, 2000. Pengembangan pertanian berkelanjutan di lahan rawa untuk mendukung ketahanan pangan dan pengembangan agribisnis : konsepsi dan strategi pengembangannya. Dalam Prosiding Seminar Nasional Penelitian dan Pengembangan Pertanian di Lahan Rawa. Cipayung, 25-27 Juli 2000.

DKP., 2008. Urgensi RUU Pengelolaan Wilayah Pesisir dan Pulau-pulau Kecil. Artikel on-line Dinas Kelautan dan Perikanan.

Dahuri, R. 1993. Model Pembangunan Sumber Daya Perikanan Secara Berkelanjutan. Dalam Prosiding Simposium Perikanan Indonesia I. Pusat Penelitian dan Pengembangan Perikanan, Ikatan Sarjana Perikanan Indonesia dan Himpunan Mahasiswa Perikanan Indonesia bekerjasama dengan Japan International Cooperation Agency. Jakarta, Indonesia. hal 297 316.

Dahuri, R. 2000. Otonomi Daerah, Peluang dan Tantangannya Dalam Sektor Kelautan dan Perikanan Indonesia. Makalah disajikan pada Seminar Nasional dan Talk Show Marine Techno and Fisheries 2000, Jakarta. 8 - 9 Agustus.

Dahuri, R. 2000. Pengembangan IPTEK Kelautan Untuk Pengelolaan Sumberdaya Kelautan. Dalam Prosiding Seminar Kelautan 2000 Peranan Ilmu Ilmiah Dalam Eksplorasi, Eksploitasi, dan Pelestarian Sumber Daya Laut. Pusat Studi Kelautan FMIPA Universitas Indonesia bekerjasama dengan Puslitbang Oseanologi LIPI. Jakarta, Indonesia. hal 33 - 48.

Davis, G.B. 1999. Kerangka Dasar Sistem Informasi Manajemen Bagian I Pengantar. Pustaka Binaman Pressindo. Jakarta, Indonesia.

Jogiyanto, H.M. 1992. Analisis dan Desain Sistem Informasi: Pendekatan Tersruktur Teori dan Praktek Aplikasi Bisnis. Andi Yogyakarta. 887 hal.

KOMNAS KAJIS KANLAUT (Komisi Nasional Pengkajian Sumber Daya Perikanan Laut). 1998. Potensi, Pemanfaatan dan Peluang Pengembangan Sumber Daya Ikan Laut di Perairan Indonesia. Puslitbang Oseanologi LIPI. Jakarta, Indonesia. 251 hal.

NOAA., 2002. Environmental Sensitivity Index Guidelines, Version 3.0. NOAA Technical Memorandum NOS OR\&R 11. Office of Response and Restoration, National Oceanic and Atmospheric Administration.

Pharmasetiawan, B., R.Mastra, B.P.Resosudarmo, S.Hakim Ad Dairi dan Y.Budiyanto. 2000. Sistim Informasi Kelautan Terpadu, Sebuah Sumbangan Konsep Untuk Pembangunan Pusat Data Kelautan di Indonesia. Makalah disajikan pada Seminar Nasional dan Talk Show Marine Techno and Fisheries 2000, Jakarta. 8- 9 Agustus.

Sari, T.E.Y. 2000. Pengembangan Sistem Informasi Perikanan di Perairan Bengkalis Propinsi Riau. M.Si Thesis Teknologi Kelautan. Institut Pertanian Bogor, Bogor, Indonesia.

Soselisa, A., 2001. Pendekatan Sistem Informasi dalam Pengelolaan Sumberdaya Perikanan. Makalah Falsafah Sains. Institut Pertanian Bogor.

Susana, T. et al., 2004. Laporan Akhir Penelitian Perairan untuk Mendukung Pemanfaatan dan Pengendalian Sumberdaya Perairan Banteng. Proyek Penelitian IPTEK Kelautan Puslit Oseanografi-LIPI, Jakarta.

Tahir, A. 2000. Kebutuhan Data dan Informasi Bagi Perencanaan Pembangunan Perikanan. Warta Pesisir dan Lautan II (04): 8-10. Pusat Kajian Sumberdaya Pesisir dan Lautan, Institut Pertanian Bogor, Bogor, Indonesia. 